\title{
HUBUNGAN PEMBERIAN ASI EKSKLUSIF TERHADA PERTUMBUHAN PANJANG BADAN DAN LINGKAR KEPALA BAYI USIA 6-9 BULAN DI POSYANDU WILAYAH KERJA PUSKESMAS ARIODILLAH PALEMBANG TAHUN 2020
}

\author{
THE RELATIONSHIP OF GIVING EXCLUSIVE BREAST MILK TO THE GROWTH OF \\ BODY LENGTH AND HEAD CIRCUMFERENCE OF BABY AGED 6-9 MONTHS AT \\ POSYANDU AREA PUSKESMAS ARIODILLAH \\ OF PALEMBANG 2020
}

\author{
Melia Rahma ${ }^{1}$, Vivi Dwi Putri ${ }^{2}$, Shinta Puspitasari ${ }^{3}$ \\ Sekolah Tinggi Ilmu Kesehatan Abdurahman Palembang, Sumatera Selatan ${ }^{1,2,3}$ \\ email: Meliarahma1990@ gmail.com¹,vividwikh04@yahoo.co.id², \\ shintapuspitasari680@gmail.com ${ }^{3}$
}

\begin{abstract}
ABSTRAK
Berdasarkan data WHO pada tahun 2016 hampir 10.000.000 anak-anak meninggal sebelum usia 5 tahun dan lebih dari 200 juta anak tidak mencapai potensi perkembangan secara optimal.Rendahnya cakupan pemberian ASI eksklusif 0-6 bulan dapat disebabkan masih kurang pemahaman masyarakat bahwa pentingnya pemberian ASI eksklusif kepada bayi.Tujuan penelitian ini untuk mengetahui hubungan pemberian ASI Eksklusif terhadap pertumbuhan panjang badan dan lingkar kepala bayi usia 6-9 bulan. Jenis penelitian ini adalah kuantitatif analitik dengan pendekatan cross sectional dengan sampel 36 responden usia bayi 6-9 bulan. Pengumpulan data dengan lembar check list dan lembar kuisioner dengan hasil uji statistik menggunakan chi square. Hasil analisis univariat di dapatkan dari 36 responden, bayi yang mendapatkan ASI sebanyak 26 bayi (72,2\%) lebih besar dari yang tidak diberikan ASI (Non ASI) yaitu 10 bayi (27,8\%). untuk panjang badan bayi yang normal yaitu 32 bayi $(88,9 \%)$, lebih besar dari yang tidak normal yaitu 4 bayi $(11,1 \%)$ lalu untuk lingkar kepala yang normal yaitu 33 bayi $(91,7 \%)$, lebih besar dari yang tidak normal yaitu 3 bayi $(8,3 \%)$. Hasil analisis bivariat Ada hubungan yang bermakna antara pemberian ASI Eksklusif terhadap pertumbuhan panjang badan bayi usia 6-9 bulan, berdasarkan hasil Chi-Square nilai $\rho$ value $=0,025$ yang lebih kecil dari $\alpha=0,05$. dan tidak ada hubungan yang bermakna antara pemberian ASI Eksklusif terhadap lingkar kepala bayi usia 6-9 bulan berdasrakan hasil dari Chi-Square nilai $\rho$ value $=0,822$ yang lebih besr dari $\alpha=0,05$.
\end{abstract}

Kata Kunci : ASI Eksklusif, Panjang Badan, Lingkar Kepala Bayi

\section{ABSTRACT}

Based on WHO data in 2016 nearly 10,000,000 children died before the age of 5 years and more than 200 million children did not reach their full development potential. The low coverage of exclusive breastfeeding 0-6 months can be caused by the lack of public understanding that the importance of exclusive breastfeeding for baby. The purpose of this study was to determine the relationship of exclusive breastfeeding to growth in body length and head circumference of babies aged 6-9 months. Typeof research is quantitative analytic design by using cross sectional approach to the total number of sample were 36 respondents aged 6-9 months. The data was collected by giving check list and questionnaire sheets with statistical test results using Chi-Square. The results of the univariate analysis were obtained from 36 respondents, 26 babies (72.2\%) who got ASI were bigger than those non-ASI, which was 10 babies (27.8\%). For a normal baby's body length was 32 babies (88.9\%), greater than abnormal was 4 babies (11.1\%), then for a normal head circumference was 33 babies (91.7\%), greater than not normal was 3 babies (8.3\%). Based on bivariate analysis results, there was a significant relationship between exclusive breastfeeding and growth in body length of babies aged 6-9 months, based on Chi-Square results $\rho$ value $=0.025<\alpha=0.05$. And there was no significant relationship between exclusive breastfeeding on head circumference of babies aged 6-9 months based on the results of Chi-Square value $\rho$ value $=0.822>\alpha=0.05$.

Keywords : Exclusive breastfeeding, Body Length, Head Circumference, Baby 


\section{PENDAHULUAN}

Pertumbuhan adalah bertambahnya jumlah dan besarnya sel diseluruh tubuh yang secara kuantitatif dapat diukur. Pertumbuhan merupakan perubahan yang terbatas pada pola fisik yang dialami oleh individu. Pertumbuhan berkaitan dengan perubahan ukuran, besar, jumlah atau dimensi pada tingkat sel, organ maupun individu. Pertumbuhan bersifat kuantitatif (dapat diukur dengan satuan), seperti berat badan ( $\mathrm{gr}, \mathrm{kg}$ ), satuan panjang $(\mathrm{cm} / \mathrm{m})$, dan sebagainya ${ }^{1}$.

Pemberian nutrisi secara mencukupi pada bayi yang harus sudah dimulai sejak dalam kandungan, yaitu dengan pemberian nutrisi yang cukup melalui ibu hamil. Setelah lahir, harus diupayakan pemberian Air Susu Ibu (ASI) secara eksklusif, yaitu pemberian ASI saja sampai anak berumur 4 samapai 6 bulan $^{2}$.

World Health Organization (WHO) merekomendasikan pemberian ASI ekslusif sekurang-kurangnya selama 6 bulan pertama kehidupan dan dilanjutkan dengan makanan pendamping sampai usia 2 tahun. Berdasarkan data WHO pada tahun 2016 terdapat puluhan juta bayi mengalami tahap tumbuh kembang dari bayi menuju dewasa dan hampir 10.000.000 anak-anak meninggal sebelum usia 5 tahun dan lebih dari 200 juta anak tidak mencapai potensi perkembangan secara optimal. Angka kejadian di Amerika sekitar bekisar $12-16 \%$ dan di Indonesia sekitar 13$18 \%$.

Kurva pertumbuhan yang diterbitkan oleh National Center for HealthStatisics (NCHS), bahwa berat badan bayi akan meningkat dua kali lipat dari berat lahir saat usia 6 bulan, berat badan bayi yang mendapat ASI lebih ringan di banding bayi yang mendapat susu formula sampai usia 6 bulan $^{3}$.

Cakupan bayi yang mendapatkan ASI eksklusif di Sumatera Selatan tahun 2017 mengalami peningkatan sebanyak $0,06 \%$ menjadi 60,0\% dibandingkan tahun 2016, yaitu $59,94 \%$ dan juga telah mencapai target RPJMN tahun 2017 sebesar 44\%. Secara provinsi, hanya 1 kab./kota $(5,9 \%)$ dengan cakupan ASI eksklusif belum mencapai target yaitu Kab, Ogan Ilir. Rendahnya cakupan pemberian ASI eksklusif 0-6 bulan dapat disebabkan masih kurang pemahaman masyarakat bahwa pentingnya pemberian ASI eksklusif kepada bayi usia 0-6 bulan, adanya promosi yang intensitaf susu formula, pemantauan sulit dilakukan, pencatatan dan pelaporan yang kurang tepat ${ }^{4}$.

Sedangkan cakupan pemberian ASI eksklusif di Kota Palembang pada tahun 2017 yaitu $77,4 \%$, sedangkan pada tahun 2016 yaitu $74,4 \%$ sehingga hal ini menunjukan bahwa terjadi peningkatan pemberian ASI eksklusif pada bayi ${ }^{4}$.

Menurut Penelitian Sartika Pandewi 2018 dengan judul hubungan pemberian ASI eksklusif dengan pertumbuhan dan perkembangan bayi usia 7-12 bulan dengan hasil terdapat hubungan antara pemberian ASI eksklusif dengan pertumbuhan bayi usia 7-12 bulan di Kendari, $2018^{5}$.

Menurut Penelitian Dwipoerwanto (2015) melakukan penelitan tentang Pengaruh Riwayat Air Susu Ibu (ASI) eksklusif Terhadap Pertumbuhan Berat Badan, Panjang Badan Dan Lingkar Lengan Aatas Bayi Berusia 6-12 bulan dengan hasil penelitian yang menunjukan bahwa pertumbuhan panjang badan, berat badan dan lingkar kepala pada bayi yang diberikan ASI eksklusif menunjukan perbedaan yang signifikan dengan bayi yang tidak diberikan ASI eksklusif ${ }^{6}$.

Tujuan penelitian ini adalah untuk mengetahui hubungan pemberian ASI Eksklusif terhadap pertumbuhan panjang badan dan lingkar Kepala pada bayi usia 6-9 bulan.

\section{METODE PENELITIAN}

Penelitian ini termasuk jenis penelitian sampelnya akan menggunakan teknik non random sampling secara purposive sampling dimana hanya mengambil sampel secukupnya. Alat pengumpulan data yang akan digunakan dalam penelitian adalah check list dan tekhik pengumpulan datanya menggunakan tekhik observasi dan menggunakan data Sekunder serta akan dianalisis menggunakan aplikasi SPSS (Statistical Package for the Social Sciences). Metode pengkuran yang digunakan dalam penelitian ini adalah pengukuran 
panjang badan bayi menggunakan pita ukur.

infantometer dan lingkar kepala menggunakan

\section{HASIL}

Tabel 1. Distribusi Frekuensi Pemberian ASI Eksklusif DiPosyandu wilayah kerja Puskesmas Ariodillah Palembang Tahun 2020

\begin{tabular}{lcc}
\hline \multicolumn{1}{c}{ Asi Eksklusif } & Frekuensi & \% \\
\hline Ya & 26 & 72.2 \\
\hline Tidak & 10 & 27.8 \\
\hline Jumlah & 36 & 100 \\
\hline
\end{tabular}

Dari 36 responden, yang diberikan ASI besar dari pada yang tidak diberikan NON ASI ekslusif sebanyak 26 responden $(72,2 \%)$ lebih yaitu sebanyak 10 responden $(27,8 \%)$.

Tabel 2. Distribusi Frekuensi Panjang Badan Terhadap Pemberian ASI Eksklusif DiPosyandu wilayah kerja Puskesmas Ariodillah Palembang Tahun 2020

\begin{tabular}{lcc}
\hline Panjang Badan & Frekuensi & \% \\
\hline Normal & 32 & 88.9 \\
\hline Tidak Normal & 4 & 11.1 \\
\hline Jumlah & 36 & 100 \\
\hline
\end{tabular}

Dari 36 responden, dengan pertumbuhan normal sebanyak 32 responden $(88.9 \%)$ lebih besar dibandingan dengan pertumbuhan

panjang badan bayi usia 6-9 bulan yang tidak normal sebanyak 4 responden $(11.1 \%)$.

Tabel 3. Distribusi Frekuensi Lingkar Kepala Terhadap Pemberian ASI Eksklusif di Posyandu wilayah kerja Puskesmas Ariodillah Palembang Tahun 2020

\begin{tabular}{lcc}
\hline Lingkar Kepala & Frekuensi & \% \\
\hline Normal & 33 & 91.7 \\
\hline Tidak Normal & 3 & 8.3 \\
\hline Jumlah & 36 & 100 \\
\hline
\end{tabular}

Dari 36 responden, dengan lingkar kepala bayi usia 6-9 bulan normal sebanyak 33 responde $(91,7 \%)$ lebih besar dibandingan dengan lingkar kepala bayi usia 6-9 bulan yang tidak normal sebanyak 3 responden $(8,3 \%)$. Dari hasil penelitian tersebut dapat disimpulkan bahwa dilihat lebih banyak bayi usia 6-9 bulan bayi dengan lingkarkepala normal dari pada lingkar kepala bayi tidak normal.

Tabel 4. Hubungan Pemberian ASI Eksklusif Terhadap Pertumbuhan panjang badan Bayi Usia 6-9 Bulan Di Posyandu wilayah kerja Puskesmas Ariodillah Palembang Tahun 2020

\begin{tabular}{|c|c|c|c|c|c|c|c|}
\hline \multirow{3}{*}{$\begin{array}{c}\text { Pemberian } \\
\text { ASI }\end{array}$} & \multicolumn{4}{|c|}{ Panjang Badan } & \multirow{2}{*}{\multicolumn{2}{|c|}{ Jumlah }} & \multirow{2}{*}{$P$ Value } \\
\hline & \multicolumn{2}{|c|}{ Normal } & \multicolumn{2}{|c|}{ Tidak Normal } & & & \\
\hline & $\mathrm{n}$ & $\%$ & $\mathrm{n}$ & $\%$ & $\mathrm{~N}$ & $\%$ & \multirow{4}{*}{0,025} \\
\hline ASI & 25 & 69,4 & 1 & 2,8 & 26 & 72,2 & \\
\hline Non ASI & 7 & 19,4 & 3 & 8,3 & 10 & 27,8 & \\
\hline Total & 32 & 88,9 & 4 & 11,1 & 36 & 100 & \\
\hline
\end{tabular}


Diketahui bahwa dari 36 responden yang memberikan ASI Eksklusif pada bayi 6-9 bulan sebanyak 26 responden $(72,2 \%)$ responden yang panjang badan bayinya normal sebanyak 25 responden $(69,4)$ dan panjang badan bayi usia 69 bualn yang tidak normal yaitu banyaknya 1 responden $(2,8 \%)$ sedangkan untuk responden yang tidak memberikan ASI atau Non ASI sebanyak 10 responden $(27,8 \%)$ masing- masing pertumbuhan panjang badan bayi usia 6-9 bualn yang normal sebanyak 7 responden $(19,4 \%)$ dan panjang badan bayi usia 6-9 bualn yang tidak normal sebanyak 3 responden $(8,3 \%)$.

Tabel 5. Hubungan ASI Eksklusif Terhadap lingkar kepala Bayi Usia 6-9 Bulan Di Posyandu wilayah kerja Puskesmas Ariodillah Palembang Tahun 2020

\begin{tabular}{|c|c|c|c|c|c|c|c|}
\hline \multirow{3}{*}{$\begin{array}{c}\text { Pemberian } \\
\text { ASI }\end{array}$} & \multicolumn{4}{|c|}{ Lingkar Kepala } & \multirow{2}{*}{\multicolumn{2}{|c|}{ Jumlah }} & \multirow{2}{*}{$P$ Value } \\
\hline & \multicolumn{2}{|c|}{ Normal } & \multicolumn{2}{|c|}{ Tidak Normal } & & & \\
\hline & $\mathbf{n}$ & $\%$ & $\mathbf{n}$ & $\%$ & $\mathbf{N}$ & $\%$ & \multirow{4}{*}{0,822} \\
\hline ASI & 24 & 66,7 & 2 & 5,6 & 26 & 72,2 & \\
\hline Non ASI & 9 & 25,0 & 1 & 2,8 & 10 & 27,8 & \\
\hline Total & 33 & 91,7 & 3 & 8,3 & 36 & 100 & \\
\hline
\end{tabular}

Diketahui bahwa dari 36 responden yang memberikan ASI Eksklusif sebanyak 26 responden $(72,2 \%)$ bayi usia $6-9$ bulan yang memiliki lingkar kepala normal sebanyak 24 responden $(66,7 \%)$ dan bayi usia 6-9 bulan yang memiliki lingkar kepala yang tidak normal sebanyak 2 responden $(5,6 \%)$ sedangkan untuk responden yang diberikan Non ASI yaitu sebanyak 10 responden $(27,8 \%)$ masing-masing 9 responden atau $25,0 \%$ yang memiliki lingkar kepala normal sedangkan 1 responden atau 2,8\% yang memiliki lingkar kepala yang tidak normal

\section{PEMBAHASAN}

Analisis Univariat

Pemberian ASI

Hasil dari penelitian ini menunjukan bahwa bayi usia 6-9 bulan di lihat dari karakteristik berdasarkan pemberian ASI Eksklusif diperoleh sebagian besar bayi yang diberikan ASI Eksklusif 26 responden (72,2\%). sedangkan yang tidak diberikan ASI atau NON ASI berjumlah 10 responden $(27,8)$.

Pada penelitian ini pemberian ASI pada bayi usia 6-9 bulan di Posyandu wilayah kerja Puskesmas Ariodillah sudah lumayan baik dan bagus bahwa keseimbangan zat-zat gizi dalam ASI dalam tingkat baik. Menurut Minarno dan Lilek Hariani (2008) yang menyatakan bahwa keseimbangan zat-zat gizi dalam ASI berada dalam tingkat terbaik dan air susunya memiliki bentuk paling baik bagi tubuh bayi yang masih muda. Pada saat yang sama, ASI juga kaya akan sari-sari makanan yang mempercepat pertumbuhan ${ }^{7}$.

Berdasarkan penelitian ini pemberian ASI Eksklusif terhadap bayi usia 6-9 bulan sangatlah penting dalam pertumbuhan karena ASI adalah satu-satunya makanan yang sesuai untuk bayi usia 6-9 bulan dan Pemberian ASI hanya diberikan ASI saja tanpa bantuan makanan atau minuman lainnya.Air Susu Ibu (ASI) adalah satu-satunya makanan yang sesuai untuk bayi sehingga harus diberikan kepada bayi dari beberapa saat setelah lahir sampai berumur 4-6 bulan. Pemberian ASI saja tanpa bantuan makanan atau minuman lainnya yang sering dibuat dengan pemberian ASI eksklusif. Pada periode ini seluruh kebutuhan gizi baik energi dan zat gizi makro maupun zat gizi mikro, utamanya vitamin mineral : telah terpenuhi dengan pemberian ASI. Namun demikian, umur 4-6 bulan, pada saat kebutuhan bayi akan seluruh zat gizi yang dibutuhkan pertumbuhan dan perkembangannya ini dibutuhkan makanan pendamping ${ }^{8}$.

\section{Panjang Badan}

Hasil dari penelitian ini menunjukan bahwa bayi usia 6-9 bulan. di lihat dari karakteristik berdasarkan pemberian ASI Eksklusif terhadap pertumbuhan panjang badan diperoleh sebagian besar bayi usia 6-9 bulan dengan pertumbuhan normal diberikan ASI Eksklusif sebanyak 32 responden (88.9\%), sedangkan yang tidak diberikan ASI atau NON ASI 
terhadap pertumbuhan tidak normal berjumlah 4 responden $(11.1 \%)$. dari hasil kesimpulan penelitian pemberian ASI Eksklusif terhadap panjang badan bayi usia 6-9 bulan, yang terdapat di Posyandu wilayah kerja Puskesmas Ariodillah palembang ini menunjukan lebih banyak responden yang normal dari pada bayi usia 6-9 bulan yang abnormal.

Pada penelitian ini pemberian ASI terhadap pertumbuhan panjang badan bayi usia 6-9 bulan di Posyandu wilayah kerja Puskesmas Ariodillah sudah lumayan baik bahwa pertumbuhan panjang badan yang normal lebih banyak yang di berikan ASI jika di bandingkan dengan tidak normal pada bayi usia 6-9 bulan. Kecukupan gizi pada anak manifestasinya dapat dilihat dari pertumbuhan anak. Penilaian terhadap pertumbuhan anak dapat dilakukan dengan berbagai cara salah satunya adalah pengukuran antropometrik. Adapun parameter ukuran antropometrik yang dipakai pada penelitian pertumbuhan fisik adalah tinggi badan, berat badan, lingkar kepala, lingkar lengan atas, dan panjang tungkai ${ }^{9}$.

\section{Lingkar Kepala}

Hasil dari penelitian ini menunjukan bahwa bayi usia 6-9 bulan. diperoleh sebagian besar bayi usia 6-9 bulan dengan pertumbuhan normal diberikan ASI Eksklusif sebanyak 33 responden $(91,7 \%)$. sedangkan yang tidak diberikan ASI atau NON ASI terhadap pertumbuhan tidak normal berjumlah 3 responden $(8,3 \%)$.

Pada penelitian ini pemberian ASI terhadap lingkar kepala bayi usia 6-9 bulan di Posyandu wilayah kerja Puskesmas Ariodillah sudah lumayan baik bahwa ukuran lingkar kepala bayi usia 6-9 bulan yang normal lebih banyak yang di berikan ASI jika di bandingkan dengan tidak normal pada bayi usia 6-9 bulan.

Bayi yang memiliki ukuran lingkar kepala normal berpeluang 5,4 kali lebih besar yang sesuai dari pada bayi yang memiliki ukuran lingkar kepala tidak normal, hubungan ini positif namun tidak signifikan secara statistik $^{10}$.

Hasil penelitian yang sama dijelaskan oleh Purwaningsih bahwa bayi usia 6-9 bulan yang diberikan ASI eksklusif lebih baik dibandingkan bayi yang diberi nutrisi selain $\operatorname{ASI}(\mathrm{p}<0,001 ; \mathrm{t}=-8,14)$.

Hasil penelitian yang sama juga dijelaskan bahwa terdapat hubungan yang signifikan $(p<0,001)$ antara pemberian ASI eksklusif terhadap lingkar kepala bayi usia 6-9 bulan ${ }^{11}$.

Pada penelitian ini juga kita bisa melihat ukuran lingkar kepala bayi usia 6-9 bulan yang normal dan tidak normal, karena pada tahun pertama akan di lakukan pemeriksaan untuk lingkar kepala bayi usia 6-9 bulan akan di ukur untuk melihat normal dan tidak normalnya. Lingkar kepala diukur setiap bulan pada tahun pertama, setiap 3 bulan pada tahun kedua, dan setiap 6 bulan pada usia 3-5 tahun. Lingkar kepala dibawah -2 SD disebut mikrosefali, dan apabila diatas +2 SD disebut makrosefali.

\section{Analisa Bivariat}

Hubungan Pemberian ASI dengan Panjang Badan

Berdasarkan uji statistik menggunakan Chi Square yang dilakukan oleh peneliti menunjukkan nilai $p$ Value $=0,025$ sehingga hipotesa menyatakan ada hubungan yang bermakna antara pemberian ASI Eksklusif terhadap panjang badan bayi usia 6-9 bulan.

Hasil penelitian ini sejalan dengan penelitian dengan judul hubungan pemberian ASI dengan tumbuh bayi umur 6 bulan di wilayah kerja puskesmas Nangalo. Hasil penilaian pada bayi yang mendaptkan ASI eksklusif sebesar 73,3\% pertumbuhannya normal dan 26,7\% pertumbuhannya kurang, sedangkan bayi pertumbuhan normal dan $37,1 \%$ adalah pertumbuhan. Nilai OR 1,62, artinya bayi yang mendapat ASI eksklusif berpeluang mendapatkan pertumbuhan normal 1,62 kali lebih besar jika dibandingkan dengan bayi ASI NON eksklusif. Uji ststistik dengan chi square didapatkan nialai $p=0,696(p \geq 0,05)$ yang menunjukkan hubungan pemberian ASI tidak signifikan dengan pertumbuhan bayi ${ }^{12}$.

Hasil penelitian tersebut sesuai dengan teori yang ada bahwa Nutrisi memiliki dampak langsung terhadap pertumbuhan, pencapaian status nutrisional yang tidak adekuat, baik disebabkan oleh malnutrisi dan/atau mal 
absorpsi dapat memperlambat pertumbuhan dan secara potensial, menyebabkan Failire To Thrive (FTT). Sebaliknya pemberian nutrisi secara berlebihan diasosiasikan dengan dengan pertumbuhan yang pesat dan dapat meningkatkan risiko pola pertumbuhan yang berbeda dibandingkan bayi yang tidak diberikan ASI eksklusif diketahui memiliki pola pertumbuhan yang berbeda dibandingkan bayi yang tidak diberikan ASI eksklusif pada tahun pertama kehidupannya. Perbedaan laju pertumbuhan yang signifikan ini pertama kali dilaporkan dalam penelitian

Davis Area Research On Lactation, Infant Nutrition And Growth (DARLING). penelitian tersebut menunjukkan bahwa bayi yang diberikan ASI tumbuh lebih cepat diawali, pada 3-6 bulan pertama, dan lebih lambat pada 6-9 bulan berikutnya ${ }^{13}$.

Pada akhir bulan ke 12, bayi yang diberikan ASI secara umum lebih ringan 500-600 gram dibandingkan bayi yang diberikan susu formula. Meta analisis dari berabgai penelitian yang membahas aspek pertumbuhan bayi juga menunjukkan bahwa bayi yang diberikan ASI selama kira-kira 12 bulan tumbuh lebih cepat pada 2 bulan awal dan lebih lambat pada bulan $3-12^{13}$.

Hubungan Pemberian ASI dengan Lingkar Kepala

Berdasarkan uji statistik menggunakan Chi Square yang dilakukan oleh peneliti menunjukkan nilai $P$ Value $=0,822$ yang lebih besar dari $\alpha=0,05$ sehingga hipotesa menyatakan tidak ada hubungan yang bermakna antara pemberian ASI Eksklusif terhadaplingkar kepala bayi bayi usia 6-9 bulan.

Berdasarkan hasil penelitian terdahulu hasil uji statistik Chi Square di peroleh nilai $P$ Value $=0,056(<0,05)$ maka dapat disimpulkan bahwa pemberian ASI Eksklusif terhadap pertumbuhan (Lingkar Kepala) bayi di posyandu Mawar Kecamatan Mersi tahun 2015.

Hasil penelitian menunjukkan bahwa semua bayi tidak mengalami gangguan pertumbuhan otak tidak ada responden yang mengalami gangguan seperti hidrosefalus, mikrosefalus, ataupun makrosefalus ${ }^{14}$.

Tujuan pengukuran lingkar kepala anak adalah untuk mengetahui lingkar kepala anak dalam batas normal atau di luar batas normalpertumbuhan ukuran lingkar kepala bayi dengan mengukur dan memantau, kelainan-kelainan yang mungkin saja terjadi pada otak akan segera bisa dideteksi, seperti mikrosefali yaitu ukuran lingkar kepala lebih kecil dari ukuran lingkar kepala normal atau makrosefali ukuran kepala lebih besar dari pada ukuran lingkar kepala normalnya ${ }^{15}$.

Hasil penelitian ini sejalan dengan teori tentang pertambahan yang relatif konstan juga dapat diketahui dari proporsi besar kepala dengan panjang badan. Saat lahir, kepala berukuran seperempat bagian dari panjang badan dan setelah dewasa, besar kepala hanya seperdelapan dari panjang badan. Oleh karena itu, lingkar kepala ini hanya efektif pada 6 bulan pertama sampai umur 2-3 tahun, kecuali pada keadaan tertentu seperti bentuk kepala yang besar pada anak yang menderita hydrocephalus. Pada usia tahun pertama ini, pertumbuhan otak relatif pesat ${ }^{16}$.

Pengukuran lingkar kepala dimaksudkan untuk menaksir pertumbuhan otak. Berat otak waktu lahir adalah sekitar 350 gram, pada usia 1 tahun beratnya hampir mencapai 3 kali lipat yaitu 925 gram $75 \%$, dan mencapai $90 \%$ pada usia 6 tahun. Pertumbuhan ukuran lingkaran kepala umumnya mengikuti pertumbuhan otak sehingga bila ada hambatan atau gangguan pada pertumbuhan lingkar kepala, pertumbuhan otak biasanya juga terhambat ${ }^{16}$.

Hasil penelitian tersebut di dapatkan teori Pengukuran lingkar kepala yaitu Pada masa pertumbuhan bayi dan balita, berlangsung perubahan ukuran dan jumlah sel, serta jaringan intraseluler pada tubuh bayi dan balita. Dengan kata lain ukuran-ukuran tubuhnya akan membesar, misalnya ditandai dengan meningkatnya berat dan tinggi badan, ukuran kepala, lingkar kepala, menguatnya tulang dan membuatnya tulang dan membesarnya otot, dan bertambahnya organ tubuh lain seperti rambut, kuku gigi, dan sebagianya. 
Salah satu cara untuk mengetahui baik atau tidaknya perumbuhan anak, adalah dengan mengukur lingkar kepalanya. Berdasarkan standar walanski, perkembangan lingkar kepala bayi dan balita berdasarkan umur terbilang normal pada ukuran berikut:

6-8 bulan : $14,75 \mathrm{~cm}$

9-11 bulan : $15,10 \mathrm{~cm}$

1 tahun : $16,00 \mathrm{~cm}$

2 tahun : $16,25 \mathrm{~cm}$

4 tahun : $16,75 \mathrm{~cm}$

5 tahun : $17,00 \mathrm{~cm}$

Ukuran di atas adalah ukuran pada pertumbuhan normal.jika ukuran lebih kecil, yaitu $85 \%$ ukuran normal, pertumbuhan anak masih kurang. Sedangkan jika ukuran lebih kecil lagi, yaitu sekitar 70\% ukuran normal, maka pertumbuhan anak buruk dan perlu asupan gizi yang lebih baik lagi ${ }^{9}$.

Hasil penelitian ini berbeda dengan teori yang dikemukakan yang mengatakan bahwa keseimbangan zat-zat gizi dalam ASI pada tingkat terbaik dan dari susunya memiliki bentuk paling baik bagi tubuh bayi yang masih muda. Pada saat semua. ASI juga kaya akan sari-sari makanan yang mempercepat pertumbuhan.

Bayi mendapat mencapai pertumbuhan optimal apabila diberi ASI Eksklusif sampai 46 bulan, dan setelah itu tetap diberikan sampai usia 2 tahun dengan diberi tambahan makanan pendamping asi ${ }^{7}$.

Dari penelitian ini juga diperoleh sekitar 24 responden $(66,7 \%)$ bayi usia 6-9 bukan yang diberi ASI Eksklusif tetapi memiliki pertumbuhan yang normal dan bayi usia 6-9 bulan yang diberikan ASI Eksklusif dengan pertumbuhan yang tidak normal sekitar 2 responden $(5,6 \%)$. dan bayi usia 6-9 bulan yang tidak diberikan ASI atau Non ASI dengan lingkar kepala yang normal sekitar 9 responden $(25,0 \%)$ sedangkan bayi usia 6-9 bulan yang tidak di berikan ASI atau Non ASI dengan lingkar kepala tidak normal sekitar 1 responden $(2,8 \%)$.

Hal ini dapat disebabkan banyak faktor sesuai dengan teori bahwa banyak faktor yang mempengaruhi pertumbuhan anak. Secara garis besar faktor-faktor tersebut dapat dibagi menjadi 2 golongan, yaitu faktor dalam (internal) dan faktor luar (eksternal/lingkungan). faktor internal terdiri dari perbedaan ras/ etnik atau bangsa, keluarga, umur, jenis kelamin, kelainan genetik, kelainan kromosom. Adanya satu kelainan genetik dan kromosom dapat mempengaruhi pertumbuhan anak, seperti yang terlihat pada anak yang menderita sindroma down. Selain faktor internal, faktor eksternal/ lingkungan juga mempengaruhi pertumbuhan anak. Faktor lingkungan yang banyak mempengaruhi pertumbuhan anak adalah gizi, stimulasi, psikologis, dan sosial ekonomi ${ }^{17}$.

Berdasarkan data yang diperoleh riwayat ASI Eksklusif tidak berhubungan terhadap pertumbuhan anak karena faktor ASI saja tidak cukup untuk mendapatkan pertumbuhan yang optimal walaupun didalam ASI terdapat zat makro maupun zat mikro yang sangat membantu dalam perkembangan anak. Tetapi setelah umur bayi lebih dari 6-9 bulan bulan ada baiknya, bayi diberikan makanan tambahan yang menunjang ASI (MP-ASI) yang dimana hal tersebut akan menghubungkan status gizi yang diberikan oleh orang tua bayi ${ }^{18}$.

Meskipun dari hasil uji statistik tidak dapat hubungan pemberian ASI Eksklusif dengan pertumbuhan, namun peneliti menganalisis lebih dalam yaitu dengan melihat jumlah bayi usia 6-9 bulan yang mengalami pertumbuhan yang tidak normal yang berjumlah 3 orang, 2 bayi usia 6-9 bulan berasal dari bayi dengan ASI Eksklusif dan 1 bayi usia 6-9 bulan dari Non ASI. Ini menunjukkan adanya perbedaan antara bayi usia 6-9 bulan yang diberikan ASI Eksklusif dan Non ASI Eksklusif.

\section{KESIMPULAN}

Terdapat hubungan yang bermakna antara pemberian ASI Eksklusif terhadap panjang badan bayi usia 6-9 bulan, berdasarkan hasil Chi-Square nilai $p$ value $=0,025$ yang lebih kecil dari $\alpha=0,05$ dan tidak ada hubungan yang bermakna antara pemberian ASI Eksklusif terhadap lingkar kepala bayi usia 6-9 bulan, berdasarkan hasil dari Chi-Square nilai $p$ value $=0,822$ yang lebih besar dari $\alpha=0,05$. 
SARAN

Dapat memberikan informasi mengenai pentingnya memberikan ASI eksklusif untuk proses pertumbuhan pada bayi terutaman pada pertumbuhan panjang badan dan lingkar kepala bayi

\section{DAFTAR PUSTAKA}

1. Soetjiningsih. 2013. Tumbuh Kembang Anak. Jakarta: EGC

2. Nursalam. 2005. Konsep Dan Penerapan Metodologi Penelitian Ilmu Keperawatan. Jakarta :Salemba Medika

3. World Health Organization. 2011. New WHO child growth standards catch on, $\mathrm{p}$. 250-251

4. Profil Dinas Kesehatan Provinsi Sumatera Selatan, 2017. Jakarta: Kementrian Indonesia RI.

5. Sartika, P. 2018. Hubungan Pemberian ASI Ekslusif dengan Pertumbuhan dan Perkembangan pada Bayi Usia 7-12 Bulan di Wilayah Kerja Puskesmas Poasia. Kediri

6. Dwipoerwantoro, P. G., Mansyur, M., Oswari, H., Makrides, M., Cleghorn, G., \& Firmansyah, A. (2015). Growth of Indonesia Compared With World Health Organization Growth Standards.Journal of Pediatric Gastroenterology and Nutrition

7. Minarno, Eko, Budi, Hariani, Lailek.2008. Gizi dan Kesehatan. UIN Malang Press:Malang.

8. Hadju, Veny. 2001. Meningkatkan Status Gizi Anak balita Melalui Perbaikan Kualitas MP-ASILokal. LP Unhas. Makassar.

9. IDAI .2014. Air susu ibu dan tumbuh kembang anak indonesia pediatricsociety.http://www.idai.or.id/arti kel/klinik/asi/air susu ibu dan tumbuh kembang anak diakses 20 Mei 2020.

10. Khomsa. 2010. Tumbuh Kembang. Status Gizi dan Imunisasi Dasar pada Balita. Yogyakarta :Nuha Medika.

11. Purwaningsih. 2009. Beberapa Faktor Yang Berhubungan Dengan Pemberian ASI Eksklusif Pada Bayi Usia 0-6 BulanDi Desa Karangawen Wilayah Kerja Puskesmas Karangawen 1 Kabupaten Demak. Semarang:Universitas Muhammadiyah Semarang

12. Dian Insana Fitri. 2015. hubungan pemberian ASI dengan tumbuh bayi umur 6 bulan di wilayahkerja puskesmas nanggalo. Yogyakarta

13. Ruth, A.L dan Robert, M.L., 2015. Breastfeeding: A Guide for the Medical Profession. ElsevierHealth Sciences.

14. Feti, K. D. 2015. Efektifitas Pemberian ASI Ekslusif terhadap Pertumbuhan dan PerkembanganBayi di Posyandu Mawar Kecamatan Mersi. Jakarta

15. Depkes RI. 2016. Profil Kesehatan Indonesia 2016. Diakses pada tanggal 5 Mei

2020.http://www.depkes.go.id/profile/kes hatan-indonesia-2015.pdf

16. Nursalam. 2005. Asuhan Keperawatan Bayi dan Anak. Jakarta : Salemba Medika.

17. Dewi, A. 2012. Asuhan Kebidanan pada Ibu Hamil Sampai dengan KB. Jakarta: EGC

18. Ikatan Dokter Anak Indonesia .2011. Tumbuh Kembang Anak dan Remaja Jakarta: Sagung Seto. 